ISSN 1392-3196 / e-ISSN 2335-8947

Zemdirbyste-Agriculture, vol. 102, No. 2 (2015), p. 123-132

DOI 10.13080/z-a.2015.102.016

\title{
Chemical properties of Pachiterric Histosol as influenced by different land use
}

\author{
Jonas VOLUNGEVIČIUS ${ }^{1}$, Kristina AMALEVIČIŪTÉ ${ }^{2}$, Inga LIAUDANSKIENË ${ }^{2}$, \\ Alvyra ŠLEPETIENÉ ${ }^{2}$, Jonas ŠLEPETYS ${ }^{2}$ \\ ${ }^{1}$ Vilnius University \\ M. K. Čiurlionio 21/27, Vilnius, Lithuania \\ ${ }^{2}$ Institute of Agriculture, Lithuanian Research Centre for Agriculture and Forestry \\ Instituto 1, Akademija, Kèdainiai distr., Lithuania \\ E-mail: kamaleviciute@gmail.com
}

\begin{abstract}
The study, aimed to determine the properties of peat soil (Pachiterric Histosol, HSs-ph) as influenced by different

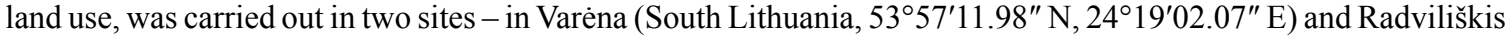

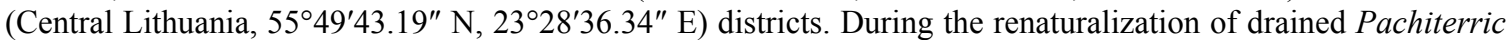
Histosol, an intensive mineralization in the $0-30 \mathrm{~cm}$ soil is taking place; therefore the concentrations of organic carbon and labile organic carbon are unfavourable for the soil. The distribution of total $\mathrm{N}$ and $\mathrm{P}$ in profile of Pachiterric Histosol is directly related to the vertical gradient of mineralization intensity; higher contents of $\mathrm{N}$ and $\mathrm{P}$ accumulated where mineralization was more intensive. The distribution of total $\mathrm{K}$ is related to land use of Pachiterric Histosol, whereas the highest quantity of total $\mathrm{K}$ was established in arable land which had been fertilised with mineral fertilizers.
\end{abstract}

Key words: Pachiterric Histosol, peat soil, renaturalization, soil organic carbon, water extractable carbon.

\section{Introduction}

Because of human activities, the concentration of atmospheric $\mathrm{CO}_{2}$ is increasing rapidly, while the longterm storage capacity of terrestrial and ocean ecosystems is declining (Canadell et al., 2007). Understanding the role played by soil in global carbon dynamics requires estimation of soil carbon stocks. In recent years increased attention has been focused on the role of soils in the global carbon cycle, where the world's soils contain roughly three times the carbon contained in all the world's vegetation and twice the amount of carbon (as $\mathrm{CO}_{2}$ ) in the earth's atmosphere (Cotrufo et al., 2011), and the changes in soil carbon content can affect the composition of the atmosphere (Lal, 2004).

On a global scale, wetland and peatland soils (Histosols) are an important reservoir of organic carbon and their use contributes to carbon emissions or accumulation processes (Rabenhorst, Swanson, 2000). Peat soils occupy about $9.54 \%$ of the Lithuanian soil cover (Motuzas et al., 2009); some of them are used for agriculture.

Organic carbon in these soils is stored in the form of plant residues in various stages of decomposition as well as in the form of heterogeneous humic compounds, which can be described as a complex mixture of macromolecules of variable chemical composition, shape and size (Zavarzina et al., 2000). The processes of peat formation and organic carbon accumulation are replaced by the processes of peat degradation, mineralization and settling of peat layer after the peat was drained. The degree of peat drainage, soil tillage, and fertilization has a significant impact on the intensity of organic matter mineralization and changes in the structure of soil profile (Szajdak et al., 2002). The published research evidence on the changes in chemical composition of peat soils under renaturalization is relevant from the environmental point of view. Considerable attention is given to anthropogenic transformation and renaturalization of these soils, which leads to changes of their chemical and physical properties. Due to the negative impact of human activity on the environment the studies of global carbon cycle and quantitative evaluations have become particularly relevant.

Soil organic matter (SOM), the main constituent of which is soil organic carbon (SOC), is derived from complicated mixture of fresh organic materials from plants, soil fauna, root exudates, microbial residues and chemically or physically protected substrates (von Lützow et al., 2007), and is one of the most complex components 
of terrestrial ecosystems and serves many vital functions in terms of regulating the flow and supply of nutrients to plants, regulating water flow and water retention in soils (Cotrufo et al., 2011). On the other hand, soil type, water regime and the composition of the mineral fraction (quantities of sand, silt and clay) can influence SOM properties. Total SOC is not always a useful indicator for monitoring purposes, and in the last decades more attention has been paid to the discrete SOC pools having different properties and rates of turnover (Kolář et al., 2009). Due to cultivation of peat soil, the ratio of total organic carbon and labile organic carbon is changed, and this affects the carbon balance in agroecosystem and contributes to the emission of $\mathrm{CO}_{2}$. Soluble water extractable organic matter is known to contribute significantly to the $\mathrm{C}$ and $\mathrm{N}$ cycles in terrestrial ecosystems (Hilli et al., 2008; Smith, 2008), soil formation and pollutant mobilization and transport (Marschner, 1999).

The content of humic substances in organic soils increases as a result of humification. Humic substances of different origins differ in composition and chemical structure, participate in sorption processes in the soil, and form soluble and insoluble complexes with cations (Donisa et al., 2003). The classic fractionation of humus is based on extracting fulvic acids, humic acids and humin that differ in solubility in various solutions of variable $\mathrm{pH}$ (Valladares et al., 2007).

Less is known about the dynamics of SOC after agricultural abandonment or renaturalization (La Mantia et al., 2007; Alberti et al., 2011); this process is connected with the development of the natural vegetation through secondary succession processes (Van Rompaey et al., 2001; Novara et al., 2011). Peat soils used for agriculture have been little investigated in Lithuania (Šlepetienè et al., 2010; Amalevičiūtè et al., 2013; 2014). One of the few experiments was carried out in Radviliškis Experimental Station of Lithuanian Institute of Agriculture in a peat bog with a removed and non-removed peat layer during 1995-2001 (Petraityte et al., 2003). Evident changes in soil properties were determined after ending of soiluse after 3-4 years (Šlepetienè et al., 2006). The effect of renaturalization on soil agrochemical properties has been investigated in a Haplic Luvisol in Voke Branch of Lithuanian Institute of Agriculture (Marcinkonis, 2007) and in a Haplic Arenosol in Perloja Experimental Station of Lithuanian Research Centre for Agriculture and Forestry (Armolaitis et al., 2011). The changes in chemical and microbiological properties of peat soil as influenced by different land-use and soil degradation processes in tropical latitudes have been examined in the United States and Indonesia (Anshari et al., 2010; Ye, Wright, 2010). The data of these studies are difficult to compare with those obtained in Lithuania due to different geographic zone. Till now little research has been done on the changes in soil profile structure, quantity and quality of organic matter as affected by drainage of low moor peat soil and its renaturalization. As indicated in literature, the changes in soil chemical composition including organic matter in peat bog soil take place much more intensively than in mineral soils.
The hypothesis of our investigation is based on the fact that after the draining of low moor shallow peat soil Pachiterric Histosol the water is replaced by the air in the soil pores, the microorganisms are activated in oxygen-enriched peat column, and they intensively use organic carbon for existence. As a result of this process, organic carbon content decreases in the upper layer of the drained Pachiterric Histosol. Changes in morphological characteristics of peat soil in vertical profile are related directly to the applied tillage and its intensity. The aim of this study was to determine the properties of a Pachiterric Histosol depending on changes in land-use, ranging over arable land, semi-natural grassland and abandoned grassland.

\section{Materials and methods}

Experimental site and conditions. A Pachiterric Histosol (HSs-ph) was investigated in this research and the treatments of different land-use in Varena district

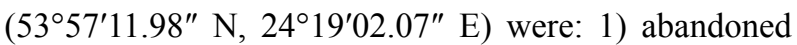
grassland, 2) arable land and 3) semi-natural grassland (uncultivated for 15 years). Specific herbal vegetation is characteristic of abandoned grassland, formed in earlier cultivated peat soil: mugwort (Artemisia vulgaris L.), common nettle (Urtica dioica L.), cleavers (Galium aparine L.), lady's bedstraw (Galium verum L.), tufted hairgrass (Deschampsia cespitosa (L.) P.Beauv.) and valerian (Valeriana officinalis L.). The surviving single cultivated plants show signs of former cultivation in arable land: sheep fescue (Festuca ovina L.) and timothy-grass (Phleum pratense L.). Potatoes (Solanum tuberosum L.) were grown in the arable land, here typical weeds were growing: potato weed (Galinsoga parviflora Cav.), common chickweed (Stellaria media (L.) Vill.), cockspur (Echinochloa crus-galli (L.) P. Beauv.), goosefoot (Chenopodium L.) and fumitory (Fumaria L.). Semi-natural grassland where the soil samples were taken is characterized by a community of cultural perennial vegetation: red clover (Trifolium pratense L.), white clover (Trifolium repens L.), smooth-stalked meadow grass (Poa pratensis L.), timothy-grass (Phleum pratense L.) and sheep fescue (Festuca ovina L.).

The Radviliškis peat bog eastern edge borders Radviliškis town (Fig. 1), and covers an area of 1203 ha $\left(55^{\circ} 49^{\prime} 43.19^{\prime \prime} \mathrm{N}, 23^{\circ} 28^{\prime} 36.34^{\prime \prime}\right.$ E). Soil samples were taken in 2012, 12 years after the completion of the field experiment. Semi-natural pasture has formed in the field of this long-term experiment. The treatments investigated in the soil with a non-removed peat layer were the following: 1) unused peat soil, 2) previously unfertilized perennial grasses, 3) crop rotation field (potatoes $\rightarrow$ winter rye $\rightarrow$ red clover), 4 ) red clover and timothy mixture and 5) perennial grasses fertilized with commercial $\mathrm{N}_{120} \mathrm{P}_{60} \mathrm{~K}_{120}$ fertilizers.

According to WRB2014(World referencebase..., 2014), this soil is referred to as eutrophic (saturated), ground water-fed, drained soil with a preserved peat structure (Eutric Rheic Drainic Fibric Histosol). In order to identify diagnostic horizons, textural composition 
and specific diagnostic characteristics of the soil, soil samples were taken in a semi-natural grassland treatment from 0-70 cm layer. Soil samples for chemical analyses were taken from $0-10,10-20$ and $20-30 \mathrm{~cm}$ layers with
6 boreholes per replicated plot in all treatments in Varèna district, in May 2013, and soil samples in Radviliškis district were taken from $0-10,10-20$ and $20-30 \mathrm{~cm}$ layers in three field replicates in August 2012 (Fig. 1).

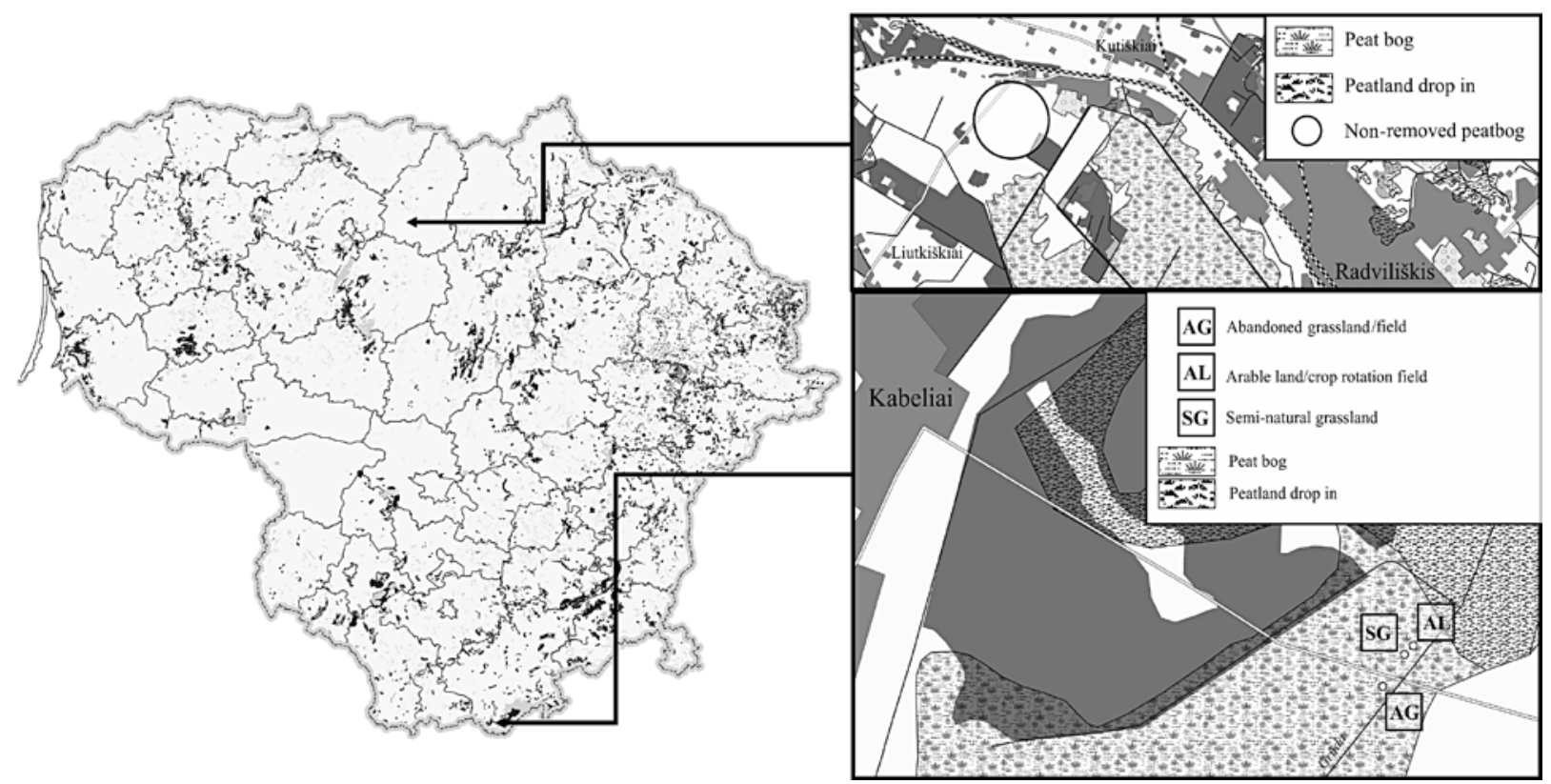

Note. Source from Lithuanian Geological Survey Information System: swamp and peat bog of Lithuania $<$ http://www.lgt.lt/ zemelap/main.php?sesName=lgt1426538027>.

Figure 1. Lithuanian sites where the Pachiterric Histosol was investigated

The Pachiterric Histosol was formed in peat bog on the gley horizon (2CR), composed of a fine layer of fine sand and silt graduated into the clay in deeper layer, and lithogenic basis. The soil profile in Varena district: $\mathrm{O}$ $(0-8 \mathrm{~cm})-\mathrm{Hsa}(8-20 \mathrm{~cm})-$ IIIH $(20-30 \mathrm{~cm})-$ IIH $(30-$ $50 \mathrm{~cm})-\mathrm{IIIH}(50-70 \mathrm{~cm})-2 \mathrm{Cr}(>70 \mathrm{~cm})$, is composed of low moor peat layers with different degree of organic matter mineralization. The depth of peat layer is about 70 $\mathrm{cm}$, and is formed by interaction of natural factors and human activities. The horizon of strongly mineralized structural drained peat (Hsa) been formed in the upper layer after the drainage had been equipped. The intensity of peat formation and decomposition processes in the deeper horizons has been determined by the climate properties: the structure-less well decayed humic peat (IIIH) where the structural plant residues was not found are resulting from wet climate, whereas the fibrous peat (IIH) consisting of medium and low decomposed plant residues was formed during the dry climate period.

The Radviliškis district soil profile is: $\mathrm{O}(0-7$ $\mathrm{cm})$ - Hs $(7-22 \mathrm{~cm})-$ IIIH $(22-32 \mathrm{~cm})-$ IIH $(30-72 \mathrm{~cm})$ $-2 \mathrm{Ckr}(>72 \mathrm{~cm})$.

Methods of analyses. Chemical analyses were carried out at the Chemical Research Laboratory of Institute of Agriculture, Lithuanian Research Centre for Agriculture and Forestry. The soil samples were airdried, crushed and sieved through a $2-\mathrm{mm}$ sieve and homogeneously mixed. Soil $\mathrm{pH}$ was determined in 1 $\mathrm{M} \mathrm{KCl}$ (soil-solution ratio 1:2.5) using potentiometric method. For the other soil analyses an aliquot of the soil samples was passed through a $0.25-\mathrm{mm}$ sieve. Soil organic carbon (SOC) content was determined by the Tyurin method modified by Nikitin (1999) with spectrophotometric measure procedure at the wavelength of $590 \mathrm{~nm}$ and glucose as a standard. Soil organic matter (SOM) content was calculated by multiplying SOC content by 1.724 . Soil total nitrogen $(\mathrm{N})$ was determined by the Kjeldhal method with photometric measure procedure at the wavelength of $655 \mathrm{~nm}$. Soil total phosphorus (P) content was determined by a photometric procedure at the wavelength of $430 \mathrm{~nm}$, and soil total potassium $(\mathrm{K})-$ by atomo-absorciometric method after wet digestion with sulphuric acid (Šlepetienè et al., 2010). Mobile humic substances were extracted using $0.1 \mathrm{M} \mathrm{NaOH}$ solution and determined according to Ponomareva and Plotnikova (1980). Water extractable organic carbon (WEOC) was determined in water extract (soil-water ratio 1:5), and measured by IR-detection method after UV-catalysed persulphate oxidation. Particle size distribution of the soil particles in the liquid dispersion was determined using the light-scattering technique Mastersizer 2000 ("Malvern Instruments", UK) which measures particles in a wide range from 2000 to $2.0 \mu \mathrm{m}$.

Statistical analyses. Significance of the differences between the means was determined according to the least significant difference (LSD) at 0.05 probability level. The experimental data were analysed by a onefactor analysis of variance method recommended in the agronomy science using ANOVA for Excel, version 6.0 (Tarakanovas, Raudonius, 2003). 


\section{Results and discussion}

About $90 \%$ of the wetlands are drained in Lithuania (source from Lithuanian Geological Survey Information System: swamp and peat bog of Lithuania). A considerable part (about 94\%) of soils in low moor peat and peaty declensions were drained in Lithuania in the second half of the $20^{\text {th }}$ century. Draining of peat soils was conducted in order to adapt them for agricultural purposes. At the same time the changes in peat mineralization were influenced in the soil profile. The most notable changes are visible in the $0-30 \mathrm{~cm}$ soil layer, and our research confirms this. The analysis of particle size distribution showed that after draining and domestication (the study was conducted in the field of cultivated perennial abandoned grassland) of Pachiterric Histosol (in Varena district), the content of 2000-500 $\mu \mathrm{m}$ size particles decreased and the content of 500-38 $\mu \mathrm{m}$ size particles increased in the upper layer, which indicates that the intensity of mineralization significantly increased in cultivated horizon $(0-30 \mathrm{~cm})$ compared to the $30-50$ and $50-70 \mathrm{~cm}$ horizons (Fig. 2). Due to chemical decomposition and formation of organicmineral complexes and aggregates, the content of clay particles $(<2 \mu \mathrm{m})$ also increased in the upper soil layer.

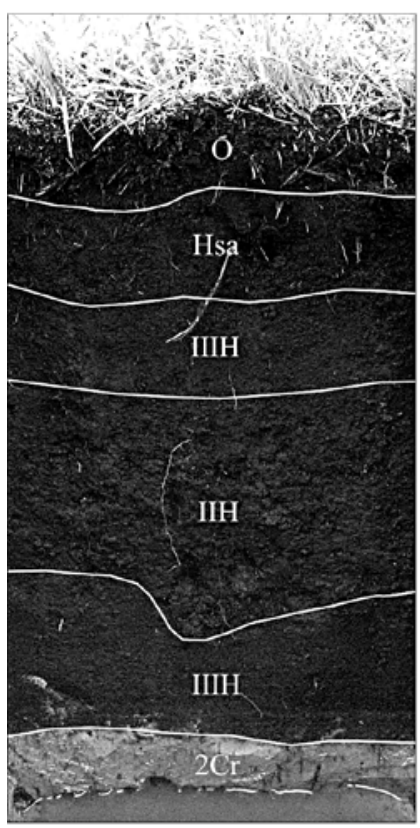

$53^{\circ} 57^{\prime} 11.98^{\prime \prime} \mathrm{N} / 24^{\circ} 19^{\prime} 02.07^{\prime \prime} \mathrm{E}$

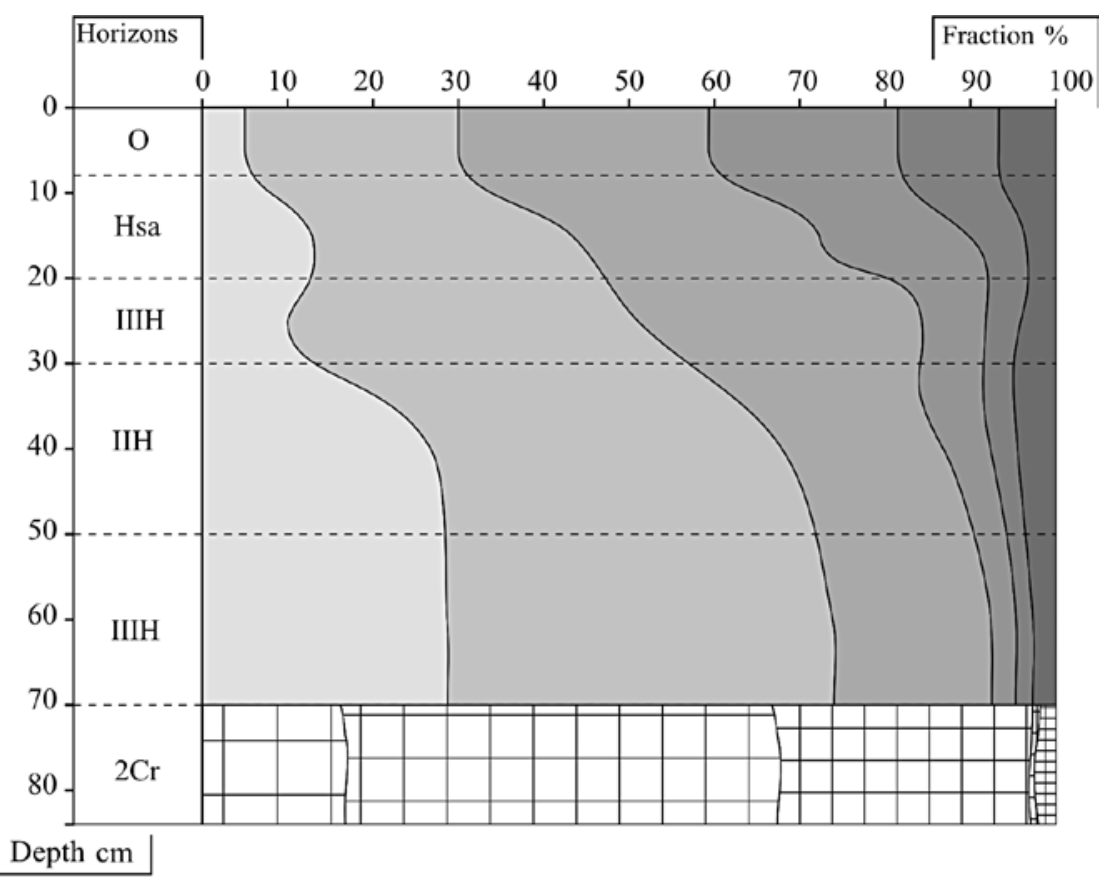

\begin{tabular}{|c|c|c|c|c|c|c|c|c|}
\hline \multirow{3}{*}{$\begin{array}{c}\text { Fractions of soil forming } \\
\text { materials }\end{array}$} & \multicolumn{8}{|c|}{ Particle sizes $\mu \mathrm{m}$ (by FAO) } \\
\hline & \multicolumn{5}{|c|}{ Sand } & \multicolumn{2}{|c|}{ Silt } & \multirow{2}{*}{$\begin{array}{l}\text { Cay } \\
(<2)\end{array}$} \\
\hline & $\begin{array}{l}\text { very coarse } \\
(2000-1000)\end{array}$ & $\begin{array}{c}\text { coarse } \\
(1000-500)\end{array}$ & $\begin{array}{l}\text { medium } \\
(500-250)\end{array}$ & $\begin{array}{c}\text { fine } \\
(250-106)\end{array}$ & $\begin{array}{l}\text { very fine } \\
(106-53)\end{array}$ & $\begin{array}{l}\text { coarse } \\
(53-38)\end{array}$ & $\begin{array}{l}\text { fine } \\
(38-2)\end{array}$ & \\
\hline Mineral & & & & & & & 曲册 & \\
\hline Organomineral & & & & & & & & \\
\hline
\end{tabular}

Figure 2. The textural composition of Pachiterric Histosol $(0-70 \mathrm{~cm})$ in the abandoned grassland (Varèna distr., 2013)

The data in Figure 3 present the changes in $\mathrm{pH}$ in Pachiterric Histosol with depth in semi-natural grassland treatment. The soil $\mathrm{pH}$ increases coherently from 5.25 in the upper $0-5 \mathrm{~cm}$ layer to 5.90 in $40-50 \mathrm{~cm}$ layer, and then $\mathrm{pH}$ decreases to 5.76 in $50-70 \mathrm{~cm}$ layer. The increase of $\mathrm{pH}$ value indicates the depth in which the peat mineralization takes place.

Due to mineralization, the SOM content (and SOC content, respectively) decreased, while WEOC content increased in the $0-30 \mathrm{~cm}$ layer of peat soil. The largest amounts of organic carbon are stored in the soil of semi-natural grassland, and accordingly lower - in the soil of arable land and abandoned grassland (Table 1). The intensive mineralization in the $0-30 \mathrm{~cm}$ layer leads to such distribution of SOC in the soil. The SOC content in the Pachiterric Histosol is unequal due to different land- use. The intensive use of peat soil (arable land treatment) results in a more intense mineralization of SOM and its depletion for agricultural production. Meanwhile, the under sowing of cultural perennial grasses and its growth in peat soil (semi-natural grassland treatment) reduces the soil tillage intensity, and thus reduces the depletion of SOM, thereby increasing the amount of SOC in the soil. Moreover, the legumes fixed atmospheric nitrogen, which later incorporated into organic compounds, and thereby contributed to the preservation of organic carbon in the soil. The lowest amounts of SOC were determined in soil of abandoned grassland. This could be predetermined by previous intensive SOM mineralization in 0-30 $\mathrm{cm}$ soil layer due to peat soil drainage as well as subsequent renaturalization processes, when the soil is not used and therefore is not added with fresh organic 


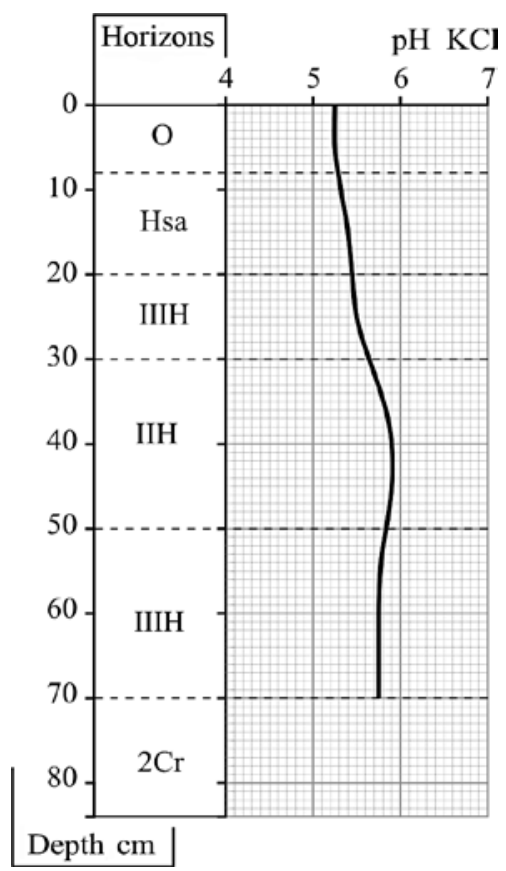

Figure 3. The $\mathrm{pH}$ of Pachiterric Histosol $(0-70 \mathrm{~cm})$ in semi-natural grassland (Varèna distr., 2013) matter. So the acidification of Pachiterric Histosol and loss of SOC continue due to the ongoing renaturalization and mineralization in $0-30 \mathrm{~cm}$ layer.

A significant increase of organic carbon in 0-20 cm layer is observed in arable land and seminatural grassland compared with abandoned grassland treatment. This could be related to ongoing agro technical management as well as organic fertilization. The processes of sod-formation occurring in the soil, as well as planting of nitrogen-fixing legumes contribute to the increase of SOC content and decrease of WEOC content, respectively. This is confirmed by the relationship between organic carbon and WEOC in the $0-10 \mathrm{~cm}$ layer in arable land treatment.

The trend of qualitative changes of organic carbon is particularly evident in semi-natural grassland. The curve shows that any peat drainage resulting in a peat mineralization reduces the SOC content and increases the content of WEOC in the soil (Fig. 4). This increases the carbon emission into the atmosphere and consequently contributes to the accumulation of greenhouse gases. The pronounced peat mineralization ends at $30 \mathrm{~cm}$ depth, this is also evident in the analysis of particle size distribution

Table 1. The $\mathrm{pH}$, soil organic carbon (SOC), soil organic matter (SOM) and water extractable organic carbon (WEOC) in different land-use of Pachiterric Histosol (Varèna distr., 2013)

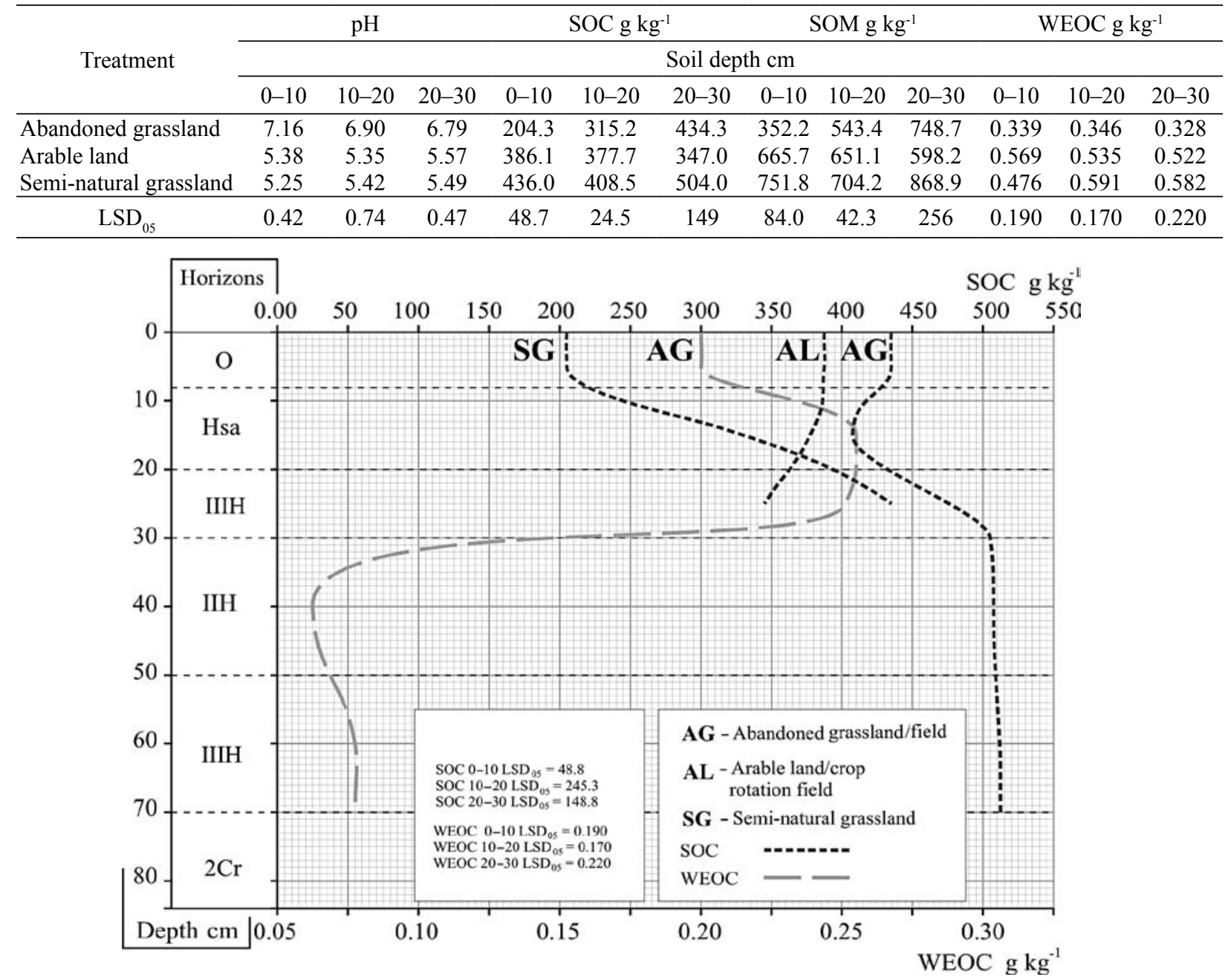

Figure 4. Peculiarities of the soil organic carbon (SOC) and water extractable organic carbon (WEOC) distribution in profile of Pachiterric Histosol under different land-use (Varèna distr., 2013) 
carried out by the laser diffractometer: the concentration of WEOC is considerably reduced and SOC content recovered at this depth, respectively (Fig. 2). Similar trends of distribution of organic carbon are observed in the soil profile of abandoned grassland. These data also emphasize the problem of mineralization in the upper $(0-30 \mathrm{~cm})$ layer of peat soil.

In order to discuss the distribution and accumulation of mobile humic substances and mobile humic acids in different peat soil layers further investigations are required throughout the entire soil profile. However, the distribution of mobile humic substances (Fig. 5) and mobile humic acids (Fig. 6) in 0-30 cm soil layer gives an indication of a direct and important influence of the land-use on the development of Pachiterric Histosol. The findings suggest that sustaining of perennial grasses land-use has a significant positive effect on the investigated peat soil, as this promoted not only accumulation of SOM, but also the increase of mobile humic acids content. If the drained peat soil is left to spontaneous renaturalization, ongoing processes of SOM mineralization result in a significant decrease in mobile humic substances (Fig. 5) and mobile humic acids (Fig. 6) content. In 20-30 cm soil layer the amounts of these compounds increased significantly; and this is a consequence of the weakening of mineralization processes, and the increasing in non-mineralized peat content.

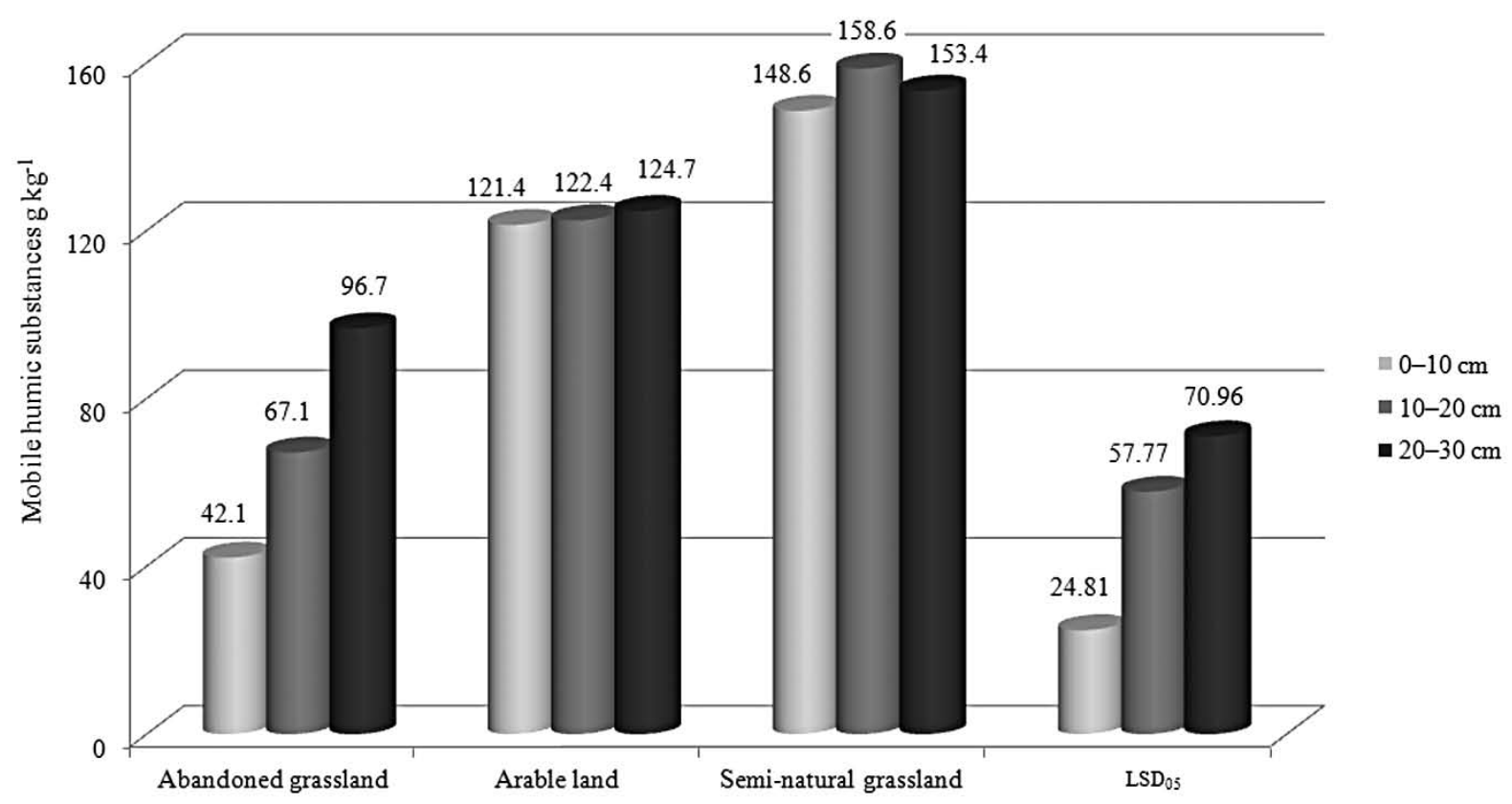

Figure 5. Content of mobile humic substances in different land-use of Pachiterric Histosol (Varèna distr., 2013)

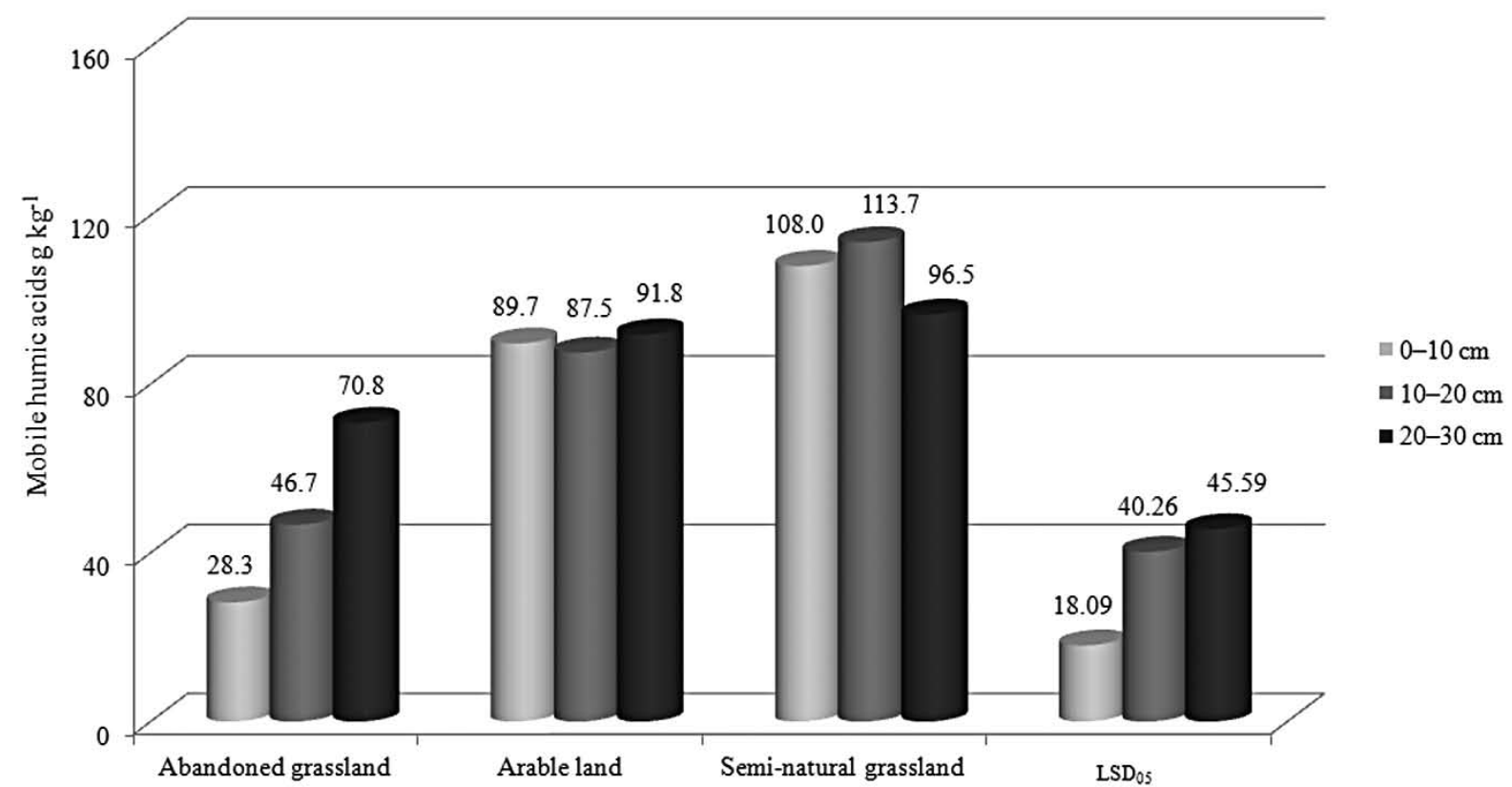

Figure 6. Content of mobile humic acids in different land-use of Pachiterric Histosol (Varèna distr., 2013) 
The same patterns are characteristic of both nitrogen and phosphorus distribution depending on the type of land-use (Table 2). Substantially higher amounts of total nitrogen $\left(22.23 \mathrm{~g} \mathrm{~kg}^{-1}\right)$ and phosphorus (1.65 g $\mathrm{kg}^{-1}$ ) are accumulated in the cultivated $0-10 \mathrm{~cm}$ layer of semi-natural grassland. These amounts are strongly reduced in the deeper layers $\left(\mathrm{N}-18.36 \mathrm{~g} \mathrm{~kg}^{-1}, \mathrm{P}-\right.$ $1.03 \mathrm{~g} \mathrm{~kg}^{-1}$ in $20-30 \mathrm{~cm}$ ). This could be influenced by fixation of atmospheric nitrogen by legumes. The lower amounts of nitrogen and phosphorus were determined in the arable land and in the abandoned grassland: $\mathrm{N}-$ 16.48, $\mathrm{P}-1.53$ and $\mathrm{N}-7.42, \mathrm{P}-0.99 \mathrm{~g} \mathrm{~kg}^{-1}$ in $0-10$ $\mathrm{cm}$ layer, respectively. In arable land these declines are caused not only by acidification of the upper soil layer and leaching of $\mathrm{N}$ and $\mathrm{P}$, but also due to the uptake of these nutrition elements to produce the yield (Fig. 3). Such their distribution is determined not only by landuse, but also by SOM sorption properties, the intensity of mineralization in 0-30 cm layer, and content of SOC and labile organic carbon. Substantial decrease of $\mathrm{N}$ and $\mathrm{P}$ in the semi-natural grassland with depth results from the fact that there are almost no nitrogen-fixing plants, and the low acidic peat leads to the unavailability of $P$. In the upper soil layer, due to the mineralization, the content of SOM and humic acids, which contribute to sorption processes, decreases and as a result the $\mathrm{N}$ and $\mathrm{P}$ concentrations in the soil decrease.

Table 2. The total soil nitrogen $(\mathrm{N})$, phosphorus $(\mathrm{P})$ and potassium $(\mathrm{K})$ content in different land-use of Pachiterric Histosol (Varèna distr., 2013)

\begin{tabular}{|c|c|c|c|c|c|c|c|c|c|}
\hline \multirow{3}{*}{ Treatment } & \multicolumn{3}{|c|}{ Soil total $\mathrm{N} \mathrm{g} \mathrm{kg}^{-1}$} & \multicolumn{3}{|c|}{ Soil total $\mathrm{P} \mathrm{g} \mathrm{kg}{ }^{-1}$} & \multicolumn{3}{|c|}{ Soil total $\mathrm{K} \mathrm{g} \mathrm{kg}^{-1}$} \\
\hline & \multicolumn{9}{|c|}{ Soil depth $\mathrm{cm}$} \\
\hline & $0-10$ & $10-20$ & $20-30$ & $0-10$ & $10-20$ & $20-30$ & $0-10$ & $10-20$ & $20-30$ \\
\hline Abandoned grassland & 7.42 & 14.84 & 17.86 & 0.99 & 0.97 & 1.41 & 0.22 & 0.20 & 0.18 \\
\hline Arable land & 16.48 & 17.63 & 18.32 & 1.53 & 1.51 & 1.52 & 1.13 & 0.83 & 0.78 \\
\hline Semi-natural grassland & 22.23 & 22.42 & 18.36 & 1.65 & 1.61 & 1.03 & 0.58 & 0.42 & 0.43 \\
\hline $\mathrm{LSD}_{05}$ & 4.20 & 6.31 & 9.76 & 0.35 & 0.50 & 1.09 & 0.76 & 0.34 & 0.24 \\
\hline
\end{tabular}

The presence of $\mathrm{K}$ in the investigated peat soil is associated with use of mineral fertilizers in agriculture, so the highest amounts of total $\mathrm{K}$ were found in arable land soil $\left(1.13,0.83\right.$ and $\left.0.78 \mathrm{~g} \mathrm{~kg}^{-1}\right)$, and the lower amounts of total $\mathrm{K}$ were in semi-natural grassland $(0.58,0.42$ and $\left.0.43 \mathrm{~g} \mathrm{~kg}^{-1}\right)$ and in abandoned grassland $(0.22,0.20$ and $\left.0.18 \mathrm{~g} \mathrm{~kg}^{-1}\right)$ in $0-10,10-20$ and $20-30 \mathrm{~cm}$ layers, respectively. Total $\mathrm{K}$ is predominantly accumulated in the upper $0-10 \mathrm{~cm}$ layer of Pachiterric Histosol, and with depth its concentration gradually decreases.

Application of the same methodology allows comparison of morphological and chemical changes in the peat soil profiles in different regions of Lithuania (Tables 1 and 3). Our study, during which the influence of different land-use on changes of Pachiterric Histosol properties was evaluated in South Lithuania, Varèna district, is closely related to the study carried out in the same soil in Central Lithuania, Radviliškis district.

These peat soils are asynchronous according to the beginning of their formation, which differ by about 3.000 years, therefore morphological differences are observed in the deeper layers of their profiles, evidencing different climatic conditions at the beginning of the formation of these soils. The peat soils in Radviliškis district are younger by age compared with the peat soils in Varena district, and therefore fewer horizons are inherent to them. The profile of peat soil in Varèna district starts from the horizon of well decomposed peat

Table 3. The $\mathrm{pH}$, soil organic carbon (SOC), soil organic matter (SOM) and water extractable organic carbon (WEOC) in different land-use of Pachiterric Histosol (Radviliškis distr., 2012)

\begin{tabular}{|c|c|c|c|c|c|c|c|c|c|c|c|c|}
\hline \multirow{3}{*}{ Treatment } & \multicolumn{3}{|c|}{$\mathrm{pH}$} & \multicolumn{3}{|c|}{$\mathrm{SOC} \mathrm{g} \mathrm{kg}^{-1}$} & \multicolumn{3}{|c|}{$\mathrm{SOM} \mathrm{g} \mathrm{kg}^{-1}$} & \multicolumn{3}{|c|}{ WEOC $\mathrm{g} \mathrm{kg}^{-1}$} \\
\hline & \multicolumn{12}{|c|}{ Soil depth $\mathrm{cm}$} \\
\hline & $0-10$ & $10-20$ & $20-30$ & $0-10$ & $10-20$ & $20-30$ & $0-10$ & $10-20$ & $20-30$ & $0-10$ & $10-20$ & $20-30$ \\
\hline Unused peat soil & 5.97 & 6.03 & 5.99 & 405.6 & 393.9 & 417.2 & 699.2 & 679.1 & 719.3 & 1.11 & 1.00 & 0.91 \\
\hline $\begin{array}{l}\text { Unfertilized perennial } \\
\text { grasses }\end{array}$ & 5.83 & 5.80 & 5.84 & 406.4 & 408.1 & 402.9 & 700.7 & 703.5 & 694.5 & 0.83 & 0.85 & 0.87 \\
\hline Crop rotation field & 6.01 & 6.00 & 5.96 & 424.0 & 417.9 & 400.4 & 731.0 & 720.5 & 690.3 & 0.87 & 0.89 & 0.85 \\
\hline $\begin{array}{l}\text { Red clover and } \\
\text { timothy mixture }\end{array}$ & 5.81 & 5.85 & 5.82 & 449.2 & 426.5 & 462.5 & 774.5 & 735.2 & 797.3 & 0.79 & 0.80 & 0.75 \\
\hline $\begin{array}{l}\text { Perennial grasses } \\
\text { fertilized with NPK }\end{array}$ & 6.05 & 5.98 & 5.67 & 481.3 & 477.3 & 468.2 & 829.7 & 822.8 & 807.2 & 0.72 & 0.70 & 0.72 \\
\hline $\mathrm{LSD}_{05}$ & 0.243 & 0.222 & 0.444 & 53.89 & 34.26 & 39.38 & 92.90 & 59.06 & 67.89 & 0.274 & 0.185 & 0.263 \\
\hline
\end{tabular}


(IIIH), followed by moderately mineralized peat horizon (IIH), and the above is strongly mineralized peat (IIIH), whereas the analysed profile of peat soil in Radviliškis district starts from IIH horizon. This evidences that at the time when the process of peat formation had already started in Southeast Lithuania, the lakes still rippled in areas of forthcoming wetlands in Northern Lithuania. The peat formation process coincides in horizons located above suggesting that the same hydro-climatic conditions of peat soil formation were all over Lithuania. However, the same morphological changes are observed in the upper part of the profile, resulting from the simultaneous anthropogenic transformation of the soils - a strong peat mineralization is observed due to peat soil drainage and ploughing in $0-30 \mathrm{~cm}$ soil layer, which leads to chemical changes in this layer. The comparison of these changes in the same type peat soils, different in age and with equal degree of cultivation in different regions of Lithuania is important not only in assessing the prospect of peat soil renaturalization, but also in optimizing of peat soil use, and in developing of the impact of different land-use on chemical properties of peat soil. Comparison of the chemical properties of peat soils in different regions allows checking the reliability of the interpretation of the obtained results and enhancing the validity of the formulated conclusions. The assumption, that the upper $0-30 \mathrm{~cm}$ peat soil layer which differs from deeper horizons both morphology and chemically is changed mainly due to land-use, has been confirmed when assessing the investigations of Pachiterric Histosol properties in different regions of Lithuania. And while in ecology context the morphology and chemical study of whole peat soil profile is essential; however, $0-30 \mathrm{~cm}$ layer remains the most important in terms of practical use. Also the assumption was confirmed that the same peat soil Pachiterric Histosol, different in age and situated in different regions, responds similarly to changes in land-use. It has been found that the largest accumulation of organic carbon in Pachiterric Histosol of different regions is the highest when peat soil is under sown with the mixture of clover and grasses. The relative decrease in organic carbon, nitrogen and phosphorus is observed in Pachiterric Histosol of both regions on arable lands according to the presented data and previous publication (Amalevičiūtè et al., 2014).

The obtained results show the same trend in the peat soils of both regions in the context of renaturalization - a decrease in total organic carbon, nitrogen and phosphorus content and an increase in labile organic carbon content take place (Tables 1 and 3). This is evidence of the further peat mineralization and negative development concerning the self renaturalization, as well as substantiates the proposition that the optimal use of drained cultured peat soils is the cultivation of perennial grasslands. The renaturalization on peat soils cannot be spontaneous but must be oriented towards the restoration of natural wetland ecosystem.

\section{Conclusions}

1. The study of the whole peat soil profile morphology and determination of its chemical characteristics is essential in pedology and ecology. However, the upper $(0-30 \mathrm{~cm})$ layer of Pachiterric Histosol is the most important in terms of practical use. The research shows that the most obvious changes in the chemical properties in the investigated soil profiles occurred in the 0-30 cm soil layer of drained Pachiterric Histosol. The same peat soil Pachiterric Histosol different in age and situated in different regions, responded similarly to changes in land-use.

2. Mineralization and organic matter transformation occurs mostly in the upper $(0-30 \mathrm{~cm})$ layer irrespective of the land-use of Pachiterric Histosol. It was identified that the highest amounts of soil organic carbon (SOC) in drained and former cultivated Pachiterric Histosol are stored in the soil of semi-natural grassland (Varèna district) and red clover - timothy mixture (Radviliškis district). In order to sequester SOC in Pachiterric Histosol the long-lived sown grasses should be grown with moderate or without any fertilization.

3. The findings suggest that sustaining of perennial grasses land-use has a significant positive effect on the investigated peat soil, as this promoted not only accumulation of soil organic matter (SOM), but also the increase of mobile humic acids content.

4. The distribution of macroelements total nitrogen $(\mathrm{N})$ and phosphorus $(\mathrm{P})$ in the profile of Pachiterric Histosol decreased with depth and it was directly related to the vertical gradient of mineralization intensity. The distribution of potassium $(\mathrm{K})$ is related to the land-use of Pachiterric Histosol, as its biggest quantity is established in arable land, which has been associated with application of commercial fertilizers.

\section{Acknowledgements}

We acknowledge the financial assistance provided by the Project VP1-3.1-ŠMM-01-V-03-001 NKPDOKT. The $3^{\text {rd }}$ and $4^{\text {th }}$ authors acknowledge the financial assistance provided by the Project VP1-3.1ŠMM-08-K-01-023 "Scientific validation of C3 and $\mathrm{C} 4$ herbaceous plants multifunctionality for innovative technologies: phyto-raw materials - bio-products environmental effects".

Received 18122014 Accepted 22052015

\section{References}

Alberti G., Leronni V., Piazzi M., Petrella F., Cairata P., Peressotti A., Piussi P., Valentini R., Cristina L., La Mantia T., Novara A., Rühl J. 2011. Impact of woody encroachment on soil organic carbon and nitrogen in abandoned agricultural lands along a rainfall gradient in Italy. Regional Environmental Change, 11 (4): 917-924 http://dx.doi.org/10.1007/s10113-011-0229-6 
Amalevičiūtė K., Šlepetienė A., Liaudanskienė I., Šlepetys J. 2013. Carbon sustainability as influenced by peaty soil use. Proceedings of the $16^{\text {th }}$ conference for junior researches Science - Future of Lithuania. Vilnius, p. 5-9

Amalevičiūtė K., Šlepetienė A., Liaudanskienė I., Šlepetys J. 2014. Chemical composition of peat bog soil and its influencing factors. Žemès ūkio mokslai, 24 (1): 1-8 (in Lithuanian)

Anshari G. Z., Afifudin M., Nuriman M., Gusmayanti E., Arianie L., Susana R., Nusantara R. W., Sugardjito J., Rafiastanto A. 2010. Drainage and land use impacts on changes in selected peat properties and peat degradation in West Kalimantan Province, Indonesia. Biogeosciences, 7: 3403-3419

http://dx.doi.org/10.5194/bg-7-3403-2010

Armolaitis K., Žèkaitė V., Aleinikovienė J., Česnulevičienė R. 2011. Renaturalization of Arenosols in the land afforested with Scot pine (Pinus sylvestrs L.) and abandoned arable land. Zemdirbyste-Agriculture, 98 (3): 275-282

Canadell J. G., Le Quere C., Raupach M. R., Field C. B., Buitenhuis E. T., Ciais P., Conway T. J., Gillett N. P., Houghton R. A., Marland G. 2007. Contributions to accelerating atmospheric $\mathrm{CO}_{2}$ growth from economic activity, carbon intensity, and efficiency of natural sinks. Proceedings of the National Academy of Sciences of the USA, 104: 18866-18870

http://dx.doi.org/10.1073/pnas.0702737104

Cotrufo M. F., Conant R. T., Paustian K. 2011. Soil organic matter dynamics: land use, management and global change. Plant and Soil, 338: 1-3 http://dx.doi.org/10.1007/s11104-010-0617-6

Donisa C., Mocanu R., Steinnes E. 2003. Distribution of some major and minor elements between fulvic ans humic fractions in natural soils. Geoderma, 111: 75-84 http://dx.doi.org/10.1016/S0016-7061(02)00254-9

Hilli S., Stark S., Derome J. 2008. Quantitative and qualitative changes in water-extractable organic compounds in the organic horizon of boreal coniferous forests. Boreal Environment Research, 13 (suppl. B): 107-119

Koláŕ L., Kužel S., Horáček J., Čechová V., Borová-Batt J., Peterka J. 2009. Labile fractions of soil organic matter, their quantity and quality. Plant, Soil and Environment, 55 (6): 245-251

Lal R. 2004. Soil carbon sequestration impacts on global climate change and food security. Science, 304: 1623-1627 http://dx.doi.org/10.1126/science.1097396

La Mantia T., Oddo G., Rühl J., Furnari G., Scalenghe R. 2007. Variation of soil carbon stocks during the renaturation of old fields: the case study of the Pantelleria Island, Italy. Forest, 4 (1): 102-109 http://dx.doi.org/10.3832/efor0433-0040102

Marcinkonis S. 2007. Renaturalization of arable land: effect on agrochemical parameters of soil quality. Žemès ūkio mokslai, 14 (2): 18-22 (in Lithuanian)

Marschner B. 1999. The sorption of polycyclic aromatic hydrocarbons and polychlorinated biphenyls in soils. Journal of Plant Nutrition and Soil Science, 162: 1-14 (in German) http://dx.doi.org/10.1002/(SICI)15222624(199901)162:1<1::AID-JPLN1>3.0.CO;2-K

Motuzas A. J., Buivydaitė V. V., Vaisvalavičius R., Šleinys R. A. 2009. Soil science. Vilnius, 336 p. (in Lithuanian)

Nikitin B. A. 1999. Methods for soil humus determination. AgroChemistry, 3 (2): 156-158

Novara A., Gristina L., La Mantia T., Rühl J. 2011. Soil carbon dynamics during secondary succession in a semi-arid
Mediterranean environment. Biogeosciences Discussions, 8: $11107-11138$

http://dx.doi.org/10.5194/bgd-8-11107-2011

Petraitytė E., Svirskienė A., Šlepetienè A. 2003. Changes in vegetation and soil as affected by different use of a peaty-bog soil. Zemdirbyste-Agriculture, 83 (3): 144-158 (in Lithuanian)

Ponomareva V. V., Plotnikova T. A. 1980. Humus and soil formation. Leningrad, Russia (in Russian)

Rabenhorst M. C., Swanson D. 2000. Histosols. Sumner M. E. (ed.). Handbook of soil science, p. 183-209

Smith P. 2008. Soil organic carbon dynamics and land-use change. Braimoh A. K., Vlek P. L. G. (eds.). Land use and soil resources, p. 9-22

Szajdak L., Maryganova V., Meysner T., Tychinskaja L. 2002. Effect of shelterbelt on two kinds of soils on the transformation of organic matter. Environment International, 28: 383-392 http://dx.doi.org/10.1016/S0160-4120(02)00059-4

Šlepetienè A., Šlepetys J., Liaudanskienė I. 2006. Investigation of organic matter status as an important indicator of anthropogenic impact for the estimation of Terric Histosol quality. Ekologija, 2: 51-58

Šlepetienè A., Šlepetys J., Liaudanskienè I. 2010. Chemical composition of differently used Terric Histosol. Zemdirbyste-Agriculture, 97 (2): 25-32

Tarakanovas P., Raudonius S. 2003. Agronominių tyrimų duomenų statistinè analizè taikant kompiuterines programas ANOVA, STAT, SPLIT-PLOT iš paketo SELEKCIJA ir IRRISTAT. Lithuanian University of Agriculture, 58 p. (in Lithuanian)

Valladares G. S., Pereira M. G., dos Anjos L. H. C., de Melo Benites V., Ebeling A. G., de Mouta R. O. 2007. Humic substance fractions and attributes of Histosols and related high-organic-matter soils from Brazil. Communications in Soil Science and Plant Analysis, 38: 763-777 http://dx.doi.org/10.1080/00103620701220759

Van Rompaey A. J. J., Govers G., Van Hecke E., Jacobs K. 2001. The impacts of land use policy on the soil erosion risk: a case study in central Belgium. Agriculture, Ecosystems and Environment, 83 (1-2): 83-94 http://dx.doi.org/10.1016/S0167-8809(00)00173-0

von Lützow M., Kögel-Knabner I., Ekschmitt K., Flessa H., Guggenberger G., Matzner E., Marschner B. 2007. SOM fractionation methods: relevance to functional pools and to stabilization mechanisms. Soil Biology and Biochemistry, 39: 2183-2207 http://dx.doi.org/10.1016/j.soilbio.2007.03.007

World reference base for soil resources. 2014. International soil classification system for naming soils and creating legends for soil maps. <http://www.fao.org/3/a-i3794e. pdf $>$ [accessed 25102014 ]

Ye R., Wright A. L. 2010. Multivariate analysis of chemical and microbial properties in Histosols as influenced by land-use types. Soil and Tillage Research, 110: 94-100 http://dx.doi.org/10.1016/j.still.2010.06.013

Zavarzina D. G., Zhilina T. N., Tourova T. P., Kuznetsov B. B., Kostrikina N. A., Bonch-Osmolovskaya E. A. 2000. Thermanaerovibrio velox sp. nov., a new anaerobic, thermophilic, organotrophic bacterium that reduces elemental sulfur, and emended description of the genus Thermanaerovibrio. International Journal of Systematic and Evolutionary Microbiology, 50: 1287-1295 http://dx.doi.org/10.1099/00207713-50-3-1287 
ISSN 1392-3196 / e-ISSN 2335-8947

Zemdirbyste-Agriculture, vol. 102, No. 2 (2015), p. 123-132

DOI 10.13080/z-a.2015.102.016

\title{
Seklaus žemapelkès durpžemio cheminės savybės, priklausomai nuo skirtingo durpžemio naudojimo
}

\author{
J. Volungevičius ${ }^{1}$, K. Amalevičiūtè2, I. Liaudanskienè ${ }^{2}$, A. Šlepetienè2 $\dot{2}^{2}$ J. Šlepetys ${ }^{2}$ \\ ${ }^{1}$ Vilniaus universitetas \\ ${ }^{2}$ Lietuvos agrarinių ir miškų mokslų centro Žemdirbystės institutas
}

\section{Santrauka}

Tyrimo tikslas - nustatyti sekliojo žemapelkès durpžemio savybes, priklausomai nuo žemės naudojimo pokyčių. Buvo tirtas žemapelkès durpžemis (Pachiterric Histosol, HSS-ph) ir analizuota skirtingo žemès naudojimo

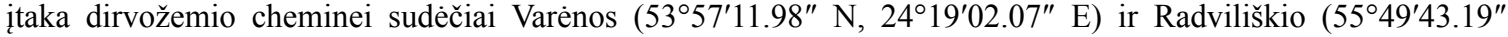
$\mathrm{N}, 23^{\circ} 28^{\prime} 36.34^{\prime \prime}$ E) rajonuose. Nusausinto durpžemio renatūralizacijos metu 0-30 cm sluoksnyje toliau vyksta intensyvi durpių mineralizacija, todèl dirvožemio organinès anglies ir labilios organinès anglies koncentracija nèra palanki dirvožemiui. Suminių N ir P pasiskirstymas sekliojo žemapelkès durpžemio profilyje yra tiesiogiai susijęs su mineralizacijos intensyvumo vertikaliuoju gradientu; didesni kiekiai $\mathrm{N}$ ir P buvo sukaupti ten, kur mineralizacija buvo intensyvesnè. Suminio K pasiskirstymas tiesiogiai priklauso nuo sekliojo žemapelkès durpžemio naudojimo būdo, nes jo didžiausia koncentracija nustatyta dirbamoje žemèje, kuri buvo tręšta mineralinèmis trąšomis.

Reikšminiai žodžiai: dirvožemio organinė anglis, durpžemis, Pachiterric Histosol, renatūralizacija, vandenyje tirpi anglis. 